\title{
PENERAPAN METODE FUN LEARNING UNTUK MENINGKATKAN HASIL BELAJAR BAHASA INDONESIA SISWA KELAS VII SMP NEGERI 1 TOMPOBULU KABUPATEN GOWA
}

\author{
Hj. Syamsiar Syahrul, S. Pd. \\ NIP. 196402121982062001, SMP Negeri 1 Tompobulu Kabupaten Gowa \\ syahrulsyamsiar@gmail.com
}

\begin{abstract}
ABSTRAK
Penelitian ini merupakan penelitian tindakan kelas, yang menjadi subjek pada penelitian adalah siswa kelas VII SMP Negeri 1 Tompobulu pada semester genap tahun pelajaran 2014/2015dengan jumlah siswa kelas eksperimen 33 siswa pengambilan data dilakukan melalui pemberian tes. Data penelitian dianalisis secara deskriftif kualitatif, dan kuantitatif. Hasil analisis secara kuantitatif menunjukkan adanya peningkatan skor rata-rata hasil belajar bahasa Indonesia siswa kelas VII SMP Negeri 1 Tompobulu kabupaten Gowa pada siklus I skor rata-rata yang dicapai adalah 54,55 sedangkan pada siklus II skor rata-rata yang dicapai dalah 77,73 dari hasil analisis secara kualitatif menunjukkan terjadinya peningkatan hasil belajar pada siswa. Selama proses pembelajaran belangsung yaitu adanya perhatian yang serta merta, konsentrasi, siswa yang tidak terpengaruh gangguan dari luar kelas, siswa yang memiliki ingatan terhadap bahan pelajaran, siswa yang tidak miliki rasa bosan, yang semakin meningkat pada setiap pertemuannya. Hasil analisis data menunjukkan bahwa baik secara kuantitatif maupun kulitatif menunjukkan adanya peningkatan hasil belajar dan keefektifan siswa setelah di ajar dengan menggunakan pembelajaran bahasa indonesia melalui metode fun learning.
\end{abstract}

Kata Kunci: Metode, fun learning, hasil belajar, dan bahasa Indonesia

\begin{abstract}
This research was class action research, which became the subject of the study were students of class VII SMP Negeri 1 Tompobulu in the second semester of academic year 2014 / 2015dengan number of students grade 33 students experimental data collection is done through the provision of a test. Data were analyzed by descriptive qualitative and quantitative. The results of quantitative analysis showed an increase in average scores Indonesian learning outcomes of students of class VII SMP Negeri 1 Tompobulu Gowa district in the first cycle the average score achieved was 54.55 while in the second cycle the average score achieved was 77,73 of the results of a qualitative analysis shows that the increase in student learning outcomes. During the learning process lasts namely their attention immediately, concentration, students who are not affected by interference from outside the classroom, students who have a memory of learning materials, students who do not have a sense of boredom, increasing at each meeting. The results of data analysis showed that both quantitative and qualitative showed an increase learning outcomes and effectiveness in teaching students after using Indonesian learning through fun learning methods.
\end{abstract}

Key words, Method, fun learning, teaching, and Indonesian language

\section{PENDAHULUAN}

Penerapan metode pembelajaran yang tepat akan memberikan hasil yang lebih baik. Oleh karena itu sangat perlu diupayakan metode pembelajaran yang dapat meningkatkan hasil belajar siswa. Upaya ini menjadi sangat penting sebab hanya melalui metode pembelajaran maka dapat meningkatkan terhadap konsep-konsep yang sedang dipelajari. Sehubungan dengan metode pembelajaran khususnya dalam pembelajaran bahasa dan sastra Indonesia, maka ada beberapa metode pembelajaran yang dapat diterapkan dalam pembelajaran bahasa Indonesia membantu siswa mencapai tujuan pembelajaran (Risnawati, 2010)

Berbagi pendekatan dan metode pembelajaran tersebut, mulai dari pendekatan kontekstual atau contextual teaching and learning (CTL), problem solving, problem posing, pembelajaran kooperatif, metode resitasi, fun learning, quantum learning, quantum teaching. Seluruh karya para ahli pendidik tersebut bertujuan membantu para siswa dalam meningkatkan hasil belajarnya (Bahri, A. 2015). Sehubungan dengan hal tersebut, perlu 
dipertimbangkan penggunaan model, pendekatan, strategi, dan metode pembelajaran yang tepat (Adrian, 2004).

Membahas persoalan pelajaran yang menyenangkan itu sangat dibutuhkan dalam proses belajar khususnya pada pendidikan bahasa Indonesia. Maka peneliti menerapkan sebuah metode fun learning yaitu cara belajar mengasyikan dan menyenangkan yang berpusat pada kondisi psikologis siswa dan atmosfir lingkungan dalam melakukan proses belajar mengajar. Metode ini merupakan cara untuk menciptakan rasa cinta dan keinginan untuk belajar (Indrahayu Sri 2010)

Adanya kendala yang menyebabkan rendahnya hasil belajar siswa tersebut menuntut guru cerdik dan inovatif dalam mencari strategi belajar yang cocok diterapkan sesuai dengan kondisi dan minat siswa. Kemampuan menerapkan metode yang baik dan dapat memilih jenis metode yang cocok untuk materi yang disajikan adalah jenis kemampuan yang dimiliki oleh guru. Kemampuan ini merupakan kunci yang dapat memudahkan siswa dalam menerima setiap materi yang diberikan oleh guru. Metode mengajar dalam proses belajar mengajar merupakan faktor penentu yang sangat penting dalam usaha pencapaian prestasi bagi siswa. Seorang guru hendaknya memiliki keterampilan dalam memilih metode mengajar yang tepat untuk digunakan dalam menyampaikan materi.

Seperti hasil yang dilakukan oleh Sri Indrahayu dengan judul yang sama namun penerapannya hanya pada mata pelajaran matematika. Dimana dalam penelitiannya dikatakan berhasil dan mendapatkan hasil yang memuaskan dalam menerapkan metode fun learning. Karena setelah menerapkan metode tersebut hasil belajar siswa lebih meningkat di banding sebelumnya. Oleh karena itu peneliti mencoba menerapkan metode fun learning pada mata pelajaran bahasa Indonesia, karena penerapan pada mata pelajaran lain mendapat hasil yang memuaskan maka peneliti ingin juga mendapatkan hasil yang memuaskan dengan menerapkan hasil yang sama.

\section{TELAAH PUSTAKA}

Ada beberapa pendapat yang dikemukakan oleh para ahli tentang pengertian belajar. Menurut Sudirman (1992:22) " belajar senantiasa merupakan perubahan tingkah laku atau penampilan, dengan serangkaian kegiatan misalnya dengan membaca, mengamati, meniru dan sebagainya"

Menurut Purwanto (1990:85) belajar adalah merupakan suatu perubahan yang terjadi melalui latihan dan pengalaman, dalam arti perubahan-perubahan yang disebabkan oleh pertumbuhan atau kematangann tidak dianggap sebagai belajar, seperti perubahan-perubahan yang terjadi pada seorang bayi.

Sudjana (1996:28) mengemukakan bahwa "belajar bukan menghapal dan bukan pula mengingat, belajar merupakan suatu proses yang ditandai denga adanya perubahan pada diri seseorang.

Slameto (2003:2) menyatakan bahwa belajar ialah " suatu proses usaha yang dilakukan seseorang untuk memperoleh suatu tingkah laku baru secara keseluruhan, sebagai hasil pengalaman sendiri dalam interaksi dalam lingkungannya"

Menurut Sahabuddin (Haling Abdul, 2007:2), belajar ialah sebagai suatu proses kegiatan yang menimbulkan kelakuan baru atau merubah kelakuan lama sehingga seseorang lebih mampu memecahkan masalah dan menyesuaikan diri terhadap situasi-situasi yang dihadapi dalam hidupnya.

Belajar bagi siswa adalah proses mencari keterkaitan atau keterhubungan antara hal-hal yang baru dengan hal-hal yang sudah diketahui. Dalam hal peran guru adalah membantu agar setiap siswa mampu menemukan keterkaitan antara pengalaman baru dengan pengalaman sebelumnya.

Berdasarkan beberapa pendapat di atas mengenai pengertian belajar, maka dapat disimpulkan bahwa perubahan tingkah laku dalam diri seseorang (individu) yang disebabkan oleh adanya suatu proses aktif yang terjadi melalui latihan dan pengalaman. Perubahan yang dimaksud di sini mencakup perubahan pengetahuan, hasil belajar, sikap dan tingkah laku, keterampilan dan kecakapan, dan kemampuan perubahan aspek kualitas yang terjadi pada diri individu.

Tolak ukur kaberhasilan proses pembelajaran dapat ditinjau dari proses dan hasil belajar yang dicapai siswa. Untuk mengukur tingkat keberhasilan proses belajar mengajar maka digunakan suatu penilaian (Talib. A, 2014). Penilaian adalah sebagai aktivitas dalam menentukan tinggi rendahnya hasil belajar itu sendiri. Hasil belajar merupakan informasi kuantitatif yang menunjukkan seberapa besarkah tingkat penguasaan materi yang telah diajarkan 
kepada siswa setelah proses belajar mengajar yang diperoleh melalui suatu penilaian. Menurut Dimyati (2002:200), hasil belajar merupakan tingkat keberhasilan yang dicapai oleh siswa setelah mengikuti suatu kegiatan pembelajaran, dimana tingkat keberhasilan tersebut kemudian ditandai dengan skala nilai berupa huruf, kata atau simbol.

Menurut Sudjana (1996:22), bahwa hasil belajar merupakan "kemampuan yang dimiliki siswa setelah ia menerima pengalaman belajar". Jadi hasil belajar adalah akibat dari suatu aktivitas yang dapat diketahui perubahannya dalam pengetahuan, pemahaman, keterampilan, dan nilai sikap melalui tes atau ujian.

Fun learning atau cara belajar yang menyenangkan dan mengasyikkan menurut pendidik komunitas sekolah alam adalah suatu proses belajar yang mengangkat kehidupan secara natural dan riil serta indah dan nyaman. Proses pembelajaran ini menjadi sebuah aktivitas kehidupan riil yang di hayati dengan penuh kegembiraan. dan menurut Tolstoy (Freire, 2004: 492) belajar menyenangkan sangat perlu dalam proses pembelajaran karena sangat membantu bagi peserta didik untuk bisa menjadikan bahan pelajaran menjadi bermakna, memberi motivasi belajar, dan menyediakan kepuasan belajar. Karena belajar yang menyenangkan akan membuat anak merasa tidak dibebani atau tidak dipaksa untuk belajar.

(Walberg dan Greenbarg, 1997) bahwa lingkungan sosial atau suasana kelas adalah penentu psikologis utama yang mempengaruhi belajar akademis. Suasana- keadaan ruanganmenunjukkan arena belajar yang dipengaruhi emosi.

Berdasarkan berapa pendapat di atas, maka dapat disimpulkan bahwa metode fun learning adalah cara belajar mengasyikkan dan menyenangkan yang berpusat pada kondisi psikologi siswa dan atmosfir lingkungan dalam melakukan proses belajar mengajar. Metode ini cara menciptakan rasa cinta dan keinginan untuk belajar. Penerapan metode ini merupakan penerpan kombinasi dari Quantum learning dan Quantum teaching dengan menggunakan games.

Penerapan metode ini membantu siswa menikmati pelajaran dengan memandang peserta didik sebagai manusia seutuhnya, bukan sebagai robot atau celengan yang harus dijejaki.

Oleh ilmu pengetahuan dan keterampilan sehingga disaat proses pembelajaran menjadi sebuah proses pengisian atau gaya bank menurut Paul of Freire (Djibran, 2006: 144).
Melalui metode pembelajaran fun learning, maka guru dapat mengubah kelas menjadi komunitas belajar masyarakat mini yang setiap detailnya telah di ubah secara saksama untuk mendukung belajar optimal yaitu dengan bagaimana cara mengatur bangku, menerapkan kebijakan kelas, hingga kepada cara merancang pengajaran. Dengan demikian siswa dinamis dapat mengikuti pembelajaran sehingga dunia guru dengan dunia siswa dapat terjembatani untuk memudahkan guru membangun jalinan, meyelesaikan bahan pelajaran dengan cepat, membuat hasil belajar lebih melekat, dan memastikan terjadinya pengalihan pengetahuan.

Bahan kunci untuk membangun suasana yang bagus adalah niat, hubungan, kegembiraan dan ketakjuban, pengambilan risiko, rasa saling memiliki, dan keteladanan.

\section{METODE PENELITIAN}

Penelitian ini merupakan penelitian tindakan kelas (PTK). Dengan tahapan pelaksanaan meliputi perencanaan, pelaksanaan, observasi, tindakan dan refleksi, secara berulang (bersiklus). Penelitian ini dilaksanakan di SMP Negeri 1 Tompobulu Kabupaten Gowa, dengan subjek penelitian adalah siswa kelasVIIa sebanyak 33 siswa tahun ajaran 2014/2015 pada semester genap.

Faktor yang diselidiki untuk menjawab masalah dalam penelitian ini adalah :

a. Faktor input yaitu dengan memperlihatkan metode yang digunakan dalam pembelajaran dan meningkatkan hasil belajar dengan menggunakan strategi belajar.

b. Faktor proses yaitu dengan melihat proses pembelajaran bahasa Indonesia dengan metode fun learning dengan menggunakan games yang langsung terkait dengan tujuan pembelajaran yang hendak dicapai dengan pengaturan kelas.

Dengan melihat hasil belajar bahasa Indonesia siswa setelah pelaksanaan tindakan pada setiap akhir siklus.

c. Faktor output

Dengan melihat hasil belajar bahasa Indonesia siswa setelah pelaksanaan tindakan pada setiap akhir siklus.

Dalam penelitian ini, instrument yang digunakan adalah: 
a. Tes akhir adalah tes yang diberikan pada siswa setelah tindakan tiap siklus.

b. Pedoman observasi, yaitu berupa catatan tentang bagaimana aktivitas siswa dalam mengikuti proses belajar.

Adapun teknik pengumpulan data yang akan dilakukan dalam penelitaian ini adalah sebagai berikut:

a. Data mengenai hasil belajar diambil dari tes tiap siklus. Tes tersebut dibuat oleh peneliti dalam bentuk soal essay yang terdiri dari 3 nomor, dimana setiap soal memunyai hasil skor yang berbeda sehingga mencapai nilai kriteria ketuntasan minimum pada mata pelajaran bahasa Indonesia dengan jawaban terbuka.

b. Data tentang aktivitas belajar mengajar diambil pada saat dilaksanakan tindakan menggunakan lembaran observasi.

Data yang diperoleh dari tes kemampuan Adapun teknik pengumpulan data yang akan dilakukan dalam penelitaian ini adalah sebagai berikut:

c. Data mengenai hasil belajar diambil dari tes tiap siklus. Tes tersebut dibuat oleh peneliti dalam bentuk soal essay yang terdiri dari 3 nomor, dimana setiap soal memunyai hasil skor yang berbeda sehingga mencapai nilai kriteria ketuntasan minimum pada mata pelajaran bahasa Indonesia dengan jawaban terbuka.

d. Data tentang aktivitas belajar mengajar diambil pada saat dilaksanakan tindakan menggunakan lembaran observasi.

dianlisis secara kuantitatif dengan menggunakan statistik deskriptif, yaitu skor ratarata, persentase, nilai minimum dan maksimum yang dicapai setiap siklus.

Untuk mengelola data hasil belajar dalam penelitian, digunakan analisis dengan prosedur sebagai berikut:

a. Merata-ratakan semua skor hasil belajar.

b. Membuat tabel kategori berdasarkan nilai rata-rata dalam kategori yaitu sangat rendah, sedang, tinggi, dan sangat tinggi.
Adapun kriteria secara deskriptif yang digunakan setelah sampai pada persentase adalah pada surat edaran Diktorat Pendidikan Menegah Umum no. 2/C3/MN/199 sebagai berikut:

Tabel 3.1 Kriteria persntase pada surat edaran Diktorat Pendidikan Menengah umum N. 288/C3/MN/199

\begin{tabular}{cc}
\hline $\begin{array}{c}\text { Persentase } \\
(\%)\end{array}$ & Tingkat \\
penguasaan \\
\hline $0-34$ & Sangat \\
$35-54$ & rendah \\
$55-64$ & Rendah \\
$65-84$ & Sedang \\
$85-100$ & Baik \\
& Sangat \\
& baik \\
\hline
\end{tabular}

Data hasil observasi dianalisis dengan cara mendiskripsikan hasil pengamatan selama proses pelaksanaan pembelajaran berlangsung.

\section{HASIL DAN PEMBAHASAN}

\section{A. Hasil belajar siswa}

1. Deskriptif hasil belajar bahasa Indonesia siswa siklus I

SMP Negeri 1 Tompobulu Berdasarkan hasil analisis deskriptif sebagaimana tercantum pada lampiran maka rangkuman statistik hasil belajar siswa kelas VIIa. Bantaeng dapat di lihat pada tabel 4.1

Tabel 4.1 statistik skor hasil belajar siswa

\begin{tabular}{lc}
\hline \multicolumn{1}{c}{ Statistik } & Nilai statistik \\
\hline Subjek & 33 \\
Skor ideal & 100 \\
Skor tertinggi & 95 \\
Skor terendah & 35 \\
Rentang skor & 55 \\
Rata-rata & 54,55 \\
\hline
\end{tabular}

Dari tabel 4.1 menunjukkan bahwa skor hasil belajar bahasa Indonesia setelah diadakan tindakan pada siklus I siswa yang di ajar dengan menggunakan metode fun learning didistribusikan ke dalam pengategorian skala lima maka hasilnya dapat di tunjukkan pada tabel.

Tabel 4.2 distribusi frekuensi dan persentase.

\begin{tabular}{lllll}
\hline $\mathrm{N}$ & Skor & Kategor & Frekuens & Persentas \\
$\mathrm{O}$ & & $\mathrm{i}$ & $\mathrm{i}$ & $\mathrm{e}$ \\
\hline
\end{tabular}




\begin{tabular}{lllll}
\hline 1 & $0-34$ & Sangat & 1 & $3,0 \%$ \\
2 & $35-$ & rendah & 12 & $36,3 \%$ \\
3 & 54 & Rendah & 10 & $30,3 \%$ \\
4 & $55-$ & Sedang & 10 & $30,3 \%$ \\
5 & 64 & Tinggi & 0 & $0 \%$ \\
& $65-$ & Sangat & & \\
& 84 & tinggi & & \\
& $85-$ & & & \\
& 100 & & & \\
\hline & Jumla & & 33 & $100 \%$ \\
& h & & & \\
\hline
\end{tabular}

Dari tabel 4.2 menunjukkan bahwa dari 33 siswa yang di ajar dengan menggunakan metode fun learning terdapat 1 siswa atau sekitar 3,0 \% skor hasil belajar bahasa Indonesia siswa berada pada kategori sangat rendah dan sekitar 12 siswa berada pada kategori rendah sekitar 36,3\%. Sedangkan dari tabel 4.1 skor hasil belajar bahasa Indonesia sebesar 72,13 berada pada rentang 3554 dengan kategori rendah, sehingga dapat disimpulkan bahwa hasil belajar bahasa indonesia siswa pada siklus I masih banyak yang belum mengerti.

2. Deskriptif hasil belajar bahasa indonesia siswa siklus II

Tabel 4.4 distribusi frekuensi skor hasil belajar siklus II

\begin{tabular}{ccccc}
\hline No & Skor & Kategori & Frekuensi & Persentase \\
& & & 0 & $0 \%$ \\
2 & $0-34$ & Sangat rendah & 0 & $0 \%$ \\
3 & $35-54$ & Rendah & 2 & $6,1 \%$ \\
4 & $55-64$ & Sedang & 21 & $63,6 \%$ \\
5 & $65-84$ & Tiggi & 10 & $30,3 \%$ \\
& $85-100$ & Sangat tinggi & & \\
\hline & & 33 & $100 \%$ \\
\hline
\end{tabular}

Dari tabel 4.4 dapat disimpulkan bahwa dari 33 siswa kelas VII.a SMP Negeri 1 Tompobulu terdapat $0 \%$ yang penguasaan materinya masuk kedalam kategori rendah $0 \%$ dalam kategori sedang 6,1\% dalam kategori tinggi $63,6 \%$ masuk dan kategori tinggi 30,3\% setelah dilaksanakan tindakan siklus II, Dengan demikian dapat disimpulkan bahwa hasil belajar bahasa Indonesia siswa kelas VIIa SMP Negeri 1 Tompobulu dengan penerapan metode fun learning dapat meningkatkan hasil belajar bahasa Indonesia siswa.

Dari skor rata-rata hasil belajar bahasa Indonesia siswa kelas VIIa SMP Negeri 1 Tompobulu setelah dilaksanakan pembelajaran
Data hasil belajar bahasa Indonesia pada siswa kelas VIIa SMP Negeri 1 Tompobulu setelah diterapkan pembelajaran melalui penerapan metode fun learning akhir siklus II diperoleh melalui pemberian tes pada akhir siklus II adapun deskriptif secara kuantitatif skor tes hasil belajar bahasa indonesia dapat di lihat pada tabel 4.3 berikut :

Tabel 4.3

\begin{tabular}{lc}
\hline \multicolumn{1}{c}{ Statistik } & Nilai statistik \\
& \\
\hline Subjek & 33 \\
Skor ideal & 100 \\
Skor & 95 \\
tertinggi & 60 \\
Skor & 75 \\
terendah & 77,73 \\
Rentang skor & \\
Rata-rata & \\
& \\
\hline
\end{tabular}

Dari tabel 4.3 skor hasil belajar bahasa indonesia siswa dikelompokkan ke dalam lima kategori, maka diperoleh distribusi frekuensi skor seperti ditunjukkan pada tabel berikut: selama II siklus dapat di lihat pada tabel sebagai berikut :

Tabel 4.5 rata-rata hasil belajar bahasa Indonesia kelas VIIa SMP Negeri 1 Tompobulu siklus I dan siklus II.

\begin{tabular}{|c|c|c|}
\hline Siklus & $\begin{array}{c}\text { Skor } \\
\text { rata-rata }\end{array}$ & Kategori \\
\hline I & 50 & Rendah \\
\hline II & 75 & Tinggi \\
\hline
\end{tabular}

Pada tabel di atas dapat di lihat bahwa skor rata-rata hasil belajar bahasa Indonesia meningkat dari 50 pada siklus pertama menjadi 75 pada siklus II. Berarti bahwa pembelajaran 
dengan penerapan metode fun learning dapat meningkatkan hasil belajar siswa kelas VIIa SMP Negeri 1 Tompobulu.

\section{B. Hasil Observasi}

a. Berdasarkan hasil observasi selama berlangsungnya penelitian dari siklus I dan siklus II tercatat sejumlah perubahan-perubahan yang terjadi pada sikap siswa terhadap bahan pembelajaran bahasa Indonesia perubahan tersebut merupakan data yang diperoleh dari lembar observasi siswa pada setiap pertemuan yang di catat oleh peneliti.

1.siklus

b. hasil penelitian :

Dari awal penelitian berlangsung sampai berakhirnya siklus II tercatat perubahan siswa yaitu:

a. Kehadiran siswa pada siklus I agak kurang

b. Antusias dalam mengikuti pelajaran masih kurang. Hal ini di lihat dari kegiatan siswa di dalam ruangan, masih ada siswa yang melakukan kegiatan lain pada proses belajar mengajar berlanggsung seperti keluar masuk ruangan.

c. Keaktifan siswa dalam proses belajar mengajar seperti menjawab pertanyaanpertanyaan tentang materi yang sedang di bahas, mengungkapkan masalah-masalah yang berkaitan dengan materi yang di ajarkan, mengkonstruksi sendiri materi yang di terima serta mengerjakan latihan di papan tulis, serta sudah ada siswa yang mengemukakan masalah-masalah yang berkaitan tentang materi yang di ajarkan dan juga sudah ada siswa yang mampu mengkonstruksi sendiri materi yang di ajarkan.

2. Siklus II

a. Kehadiran siswa semakin meningkat dan antusias memperhatikan pelajaran, walaupun masih ada beberapa siswa yang melakukan kegiatan lain pada saat menjelaskan.

b. keaktifan siswa dalam mengikuti proses belajar mengajar semakin meningkat sepetri menjawab pertanyaan guru, bertanya tentang materi yang sedang di bahas, dan mengerjakan soal-soal di papan tulis hampir semua siswa aktif dalam proses belajar mengajar bahkan mereka bersaing ingin kelompoknya unggul.

c. siswa yang mampu mengemukakan masalah-masalah yang berkaitan dengan materi dan siswa yang mampu mengkonstruksi sendiri materi yang di terima sudah menunjukkan adanya peningkatan.

d. siswa sudah mampu mengerjakan latihan tanpa harus meminta bimbingan pada guru karena rasa kerjasamanya sudah ada, melainkan meminta penjelasan kepada temannya saja yang sudah paham.

e. siswa yang mengerjakan latihan pada lembar kerja dengan benar semakin meningkat berkat adanya kerja sama antara anggota kelompok.

\section{Refleksi terhadap pelaksanaan dalam proses belajar mengajar bahasa Indonesia.}

1. Refleksi siklus I

Pada siklus I dibagi dalam lima kelompok dimana tiap kelompok ada yang 5 orang dan 6 orang dari 33 siswa, pembagian anggota kelompok di pilih secara acak pada awalnya sebagian cenderung tidak puas dengan cara pembagian kelompok tersebut karena mereka menginginkan teman kelompoknya yang sudah akrab dengan teman mereka tetapi ada juga yang merasa senang dengan pembagian secara acak, supaya mereka lebih akrab dengan teman yang lain.

Pembelajaran pada siklus I secara umum siswa belum mampu menemukan masalahmasalah yang berkaitan dengan materi yang di ajarkan belum mampu menginstruksi sendiri pengetahuannya.

\section{Refleksi siklus II}

Siklus I peneliti mengalami sedikit kesulitan pada pertemuan pertama dalam pembentukan kelompok karena siswa tidak ingin anggota kelompoknya diubah namun pada pertemuan kedua dan seterusnya dalam proses belajar mengajar sudah mengalami peningkatan.

Siklus II siswa semakin memperlihatkan kemajuan hal ini ditandai jumlah siswa yang menjawab pertanyaan guru, bertanya tentang materi yang di ajarkan, serta beberapa siswa mampu mengemukakan masalah-masalah yang berhubungan dengan materi pelajaran dan siswa mampu mengemukakan sendiri pengetahuannya.

Kerjasama antara anggota kelompok meningkat, dilihat seperti siswa yang di tunjuk dapat memiliki kembali kelompoknya 
mengerjakan soal-soal yang diberikan. secara umum dikatakan bahwa seluruh kegiatan siklus II mengalami peningkatan dibanding dengan siklus I.

\section{Pembahasan}

Penerapan metode fun learning dalam pembelajaran bahasa Indonesia meningkatkan hasil belajar siswa, dalam pelaksanaannya siswa berkesempatan berbagi pengalaman dan pemahaman dengan teman-temannya. Dasarnya adalah bahwa belajar adalah salah satu kunci dasar efektifitas penerapan metode fun learning dalam meningkatkan hasil belajar yang terjadi pada dirinya sendiri.

Adapun materi yang di bahas yaitu tentang merancang model bahasa Indonesia dari masalah yang berkaitan dengan materi yang di ajarkan, pertama-tama siswa di tuntut untuk mengkonstruksi materi sendiri dengan pikirannya untuk dapat menemukan cara-cara atau model bahasa Indonesia yang ada pada sebuah soal dan di tuntut untuk membahas dengan teman kelompoknya, setelah mendiskusikannya dengan masing-masing teman kelompoknya, maka setiap kelompok mempersentasekannya di depan kelas sedangkan kelompok lain menanggapi dan bertanya. Kemudian di lakukan refleksi untuk melihat apa saja yang telah di kerjakan sebelumnya guru yang akan memberikan penilaian mengenai hasil kerja mereka dengan salah satu cara memberikan suatu penghargaan.

Selama kegiatan proses belajar mengajar berlangsung, pada siklus I siswa terlihat sudah mulai termotivasi untuk mengikuti pelajaran bahasa Indonesia di sebabakan adanya kerja kelompok apa yang mereka ketahui hal ini di sebabkan penerapan metode fun learning.

Siklus I terlihat adanya peningkatan hasil belajar yang di capai siswa berada pada kategori sedang, setelah di adakan refleksi kegiatan pada siklus I maka di lakukan beberapa perbaikan kegiatan yang di anggap perlu demi peningkatan hasil belajar siswa pada siklus II, dilihat dari jumlah kehadiran, siswa sudah mulai aktif bertanya dan menjawab pertanyaan guru demi keberhasilan kelompoknya. Siswa merasa senang ketika diberi kesempatan untuk mengemukakan masalah yang berhubungan dengan materi pelajaran. Siswa yang mampu mengkonstruksi sendiri pengetahuannya sudah mengalami kemajuan. Hal ini disebabkan karena komunikasi antara siswa sudah terjalin setelah diberikan tes siklus II skor rata-rata yang di capai berada pada kategori tinggi di bandingkan dengan siklus I maka dapat disimpulkan bahwa penerapan metode fun learning dapat meningkatkan hasil belajar siswa kelas VIIa SMP Negeri 1 Tompobulu Kabupaten Gowa.

\section{KESIMPULAN}

Penyajian hasil penelitian dan pembahasan penelitian tentang peningkatan hasil belajar bahasa Indonesia melalui penerapan metode fun learning pada siswa kelas VIIa SMP Negeri 1 Tompobulu Kabupaten Gowa hasil penelitian menunjukkan bahwa:

1. Hasil belajar siswa pada pelajaran bahasa Indonesia setelah diterapkannya metode fun learning dapat dilihat pada siklus I dikategorikan sedang dengan nilai rata-rata sebesar 54,55 dan pada siklus II meningkat menjadi kategori sangat tinggi dimana nilai rata-rata sebesar 77,73.

2. Penerapan metode fun learning pada siswa kelas VIIa SMP Negeri 1 Tompobulu mengalami peningkatan. Selain itu penelitian sebelumnya yang dilakukan oleh Sri Indrahayu dengan judul yang sama hanya penerapannya pada mata pelajaran matematika. Dalam penelitiannya dikatakan berhasil dan memuaskan. Hal inilah yang kemudian menguatkan bahwa penggunaan metode fun learning sangat cocok untuk diterapkan guna meningkatkan hasil pembelajaran siswa.

Melalui metode fun learning dapat meningkatkan keaktifan siswa dalam belajar. Indikator peningkatan tersebut dapat dicermati berdasaarkan hasil observasi siswa dari siklus I dan siklus II yang mengalami perubahan, terutama perubahan sikap,motivasi dan hasil belajar siswa dalam memahami materi.

\section{DAFTAR PUSTAKA}

Anni Chatarinati. 2004. Psikologi belajar. Semarang: UPT MKK UNNES.

Adrian. 2004. Peningkatan hasil belajar bahasa Indonesia melalui penerapan resitasi. $U M M$.

Bahri, A. (2015). Peningkatan kemampuan membaca intensif dengan menggunakan 
metode sq4r (survey, read, review, recite, reflect) di kelas VIII SMP. Guppi Samata Gowa. JURNAL PENDIDIKAN KONFIKS, 2(1).

De Porter, Bobi Mark Reordon dan Sarah Singernoure, 2003. Quantum Learning: mempraktikkan Quantum Learning diruang-ruang Kelas. Bandung kaifa.

De Porter, Bobi Mark Reordon dan Sarah Singernoure, 2008. Quantum teaching: mempraktikkan Quantum teaching diruang-ruang Kelas. Bandung kaifa.

Dimyanti, 2002. Belajar dan pembelajaran. Jakarta. Rineka Cipta.

Djamarah. 2003. Strategi Belajar mengajar. Jakarta. Rineka Cipta

Djibran,fahd. 2006. Revolusi sekolah. mizan. Bandung http/www. Republika on line artikel pendidikan network.

Goleman, Daniel. 1995 Emotional intelligences. New York: Bantam Books.

Hamalik Omar, 2001. Proses belajar mengajar. Jakarta. Rineka Cipta.

Haling, Abdul. 2007. Belajar dan pembelajaran. Universitas negeri Makassar

Indrahayu Sri, 2010. Peningkatan hasil belajar matematika melalui penerapan metode fun learning. UMM.

Purwanto, 1990. Pisikologi pendidikan. Bandung: PT Remaja Rasdakarya.

Risnawati. 2010. Meningkatkan hasil belajar bahasa Indonesia melalui pendekatan CTL.UMM.

Slameto. 1991. Prose Belajar mengajar dalam sistem kredit semester. Jakarta:Rineka Cipt

Sanjaya,w. 2006. Pembelajaran dalam implementasi kurikulum berbasis kompetensi, media group. Jakarta kencana.
Singer, Blair.1997.Pembicara. code of honor, Nevada: Xcel

Slameto, 2003. Belajar dan faktor-faktor yang mempengaruhinya. Jakarta: Rineka Cipta.

Sudirman, A.M. 2003. Interaksi dan motivasi belajar mengajar. Jakarta: PT Raja Grafindo Persada.

Sudjana, N. 1996. Cara Belajar Siswa Aktif Dalam Proses Mengajar. Bandung: Sinar Baru Algensindo.

Talib, A. (2016). Peningkatan kemampuan membuat kalimat tanya melalui games jeopardy siswa kelas v SDN No. 13 Allu kecamatan Bangkala Kabupaten Jeneponto. JURNAL PENDIDIKAN KONFIKS, 1(1).

Walberg, Herberg dan Greenberg,Rebecca.(mei, 1997) "Using the Learning Environmeninventory, "Education Leadership 54,8:45-46

Wiryawan. 1990. Strategi belajar mengajar. Departemenpendidikan dan kebudayaan. Universitas terbuka Jakarta. 